\title{
The Effect of Removal of Baggage Facilities on Customer Satisfaction at Wings Air
}

Satriyadin',

Sri Ernawati ${ }^{2}$

1,2 Marketing Management, Sekolah Tinggi Ilmu Ekonomi Bima, NTB. Indonesia

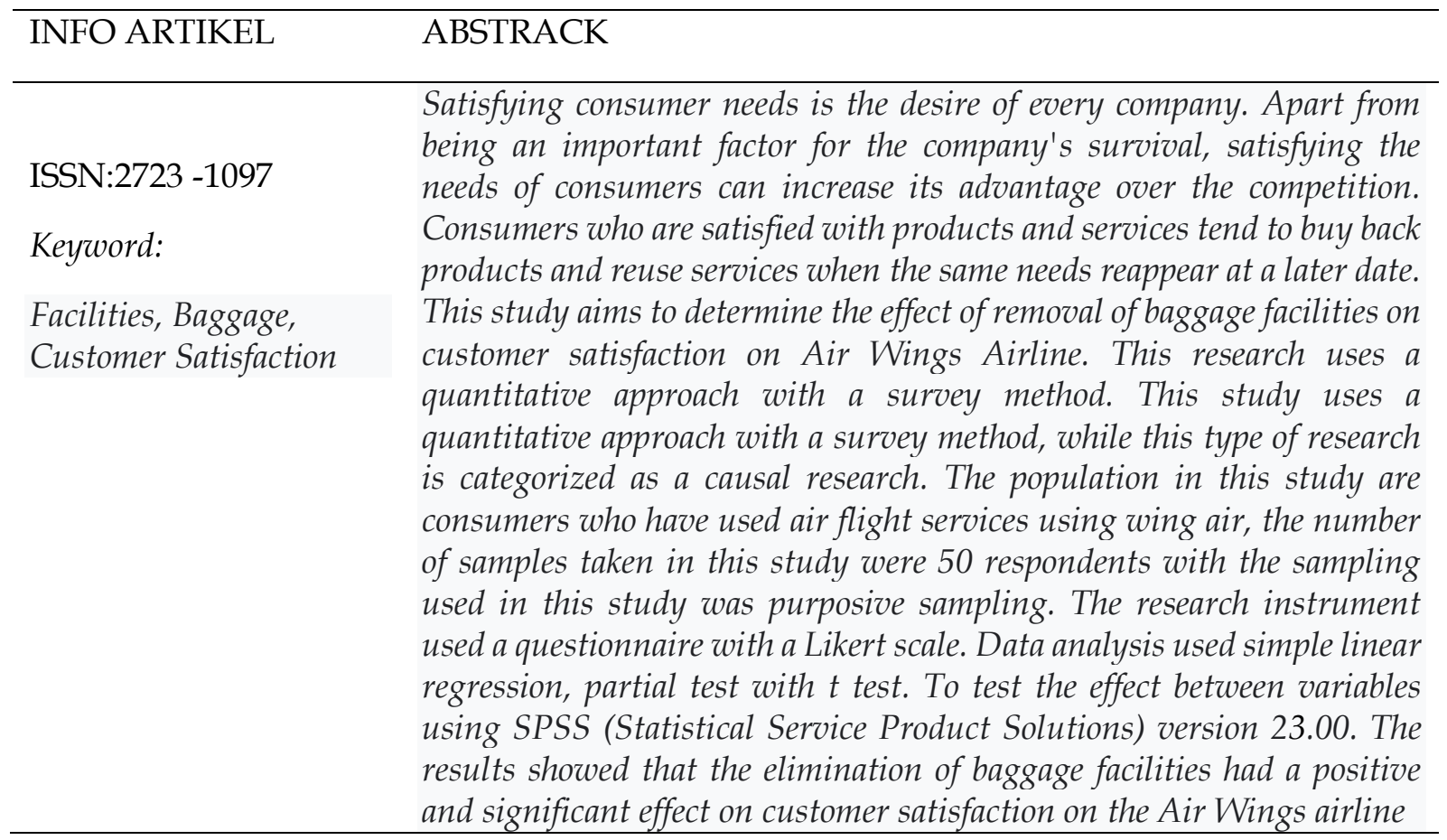

\section{Introduction}

The conditions for business opportunities in Indonesia are very good. This can be seen from the number of companies that have sprung up, whether they are engaged in services or goods. Quality service products have an important role in shaping customer satisfaction. The more facilities and services provided, the higher the satisfaction felt by customers or consumers (Markus, 2020). The current economic development has given rise to tighter competition, especially in similar sectors. Companies must keep up with current developments in order to retain or attract existing market share. With increasing competition, business people are required to maximize the performance of one of them through facilities (William \& Purba, 2020)

The development of airline services from year to year is increasingly becoming the attention of the wider community. This can be seen from the intense competition for

Journal of Business and Management Review Vol. 2 No. 62021 Page 374-383

DOI: $10.47153 /$ jbmr25.1372021

*Corresponding Author

Email address: sriernawati.stiebima@gmail.com 
services, prices and promotions offered by various airlines. The attractiveness of the aviation industry is large and promising. This can be seen from the number of aviation industries that are in this business. The trend of increasing population mobility, both for work, family visits, and tourism, along with the increasing purchasing power of the community, boosts its own potential for the aviation industry (Sadiqin \& Saraswati, 2018).

Today's business development has been characterized by various kinds of competition in all fields. Seeing this condition causes business people to be increasingly required to have the right strategy in meeting sales volume targets, Customer satisfaction can be said to be an important point of a business by service companies. This is what a service company is aiming for where customers feel their expectations of all facilities or service can be fulfilled properly (Srijani \&Hidayat, 2017). The physical resource facilities that must exist before a service can be offered to consumers. Facilities can also be anything that makes it easier for consumers to get satisfaction (Lumentut \& Palandeng, 2014). Facilities are the provision of physical equipment to make it easier for guests to carry out their activities or activities, so that their needs can be met (Yunus \& Budianto, 2014).

There are factors that affect customer satisfaction. In this study, the variables taken were facilities. Facilities are the provision of physical equipment to make it easier for guests to carry out their activities or activities (Sulastiyono, 2011), because facilities are one of the important components for life, the company must be able to manage it well throughout its life, so that it can always function properly, economically, efficiently and effectively, Soemitro \& Suprayitno, (2018). The facilities used in the process of departure and arrival of passengers are called the level of service, including: passenger and baggage checks, check-in services, departure immigration, arrival immigration, customs services, departure waiting rooms and baggage services. Facilities that provide comfort to passengers include: temperature conditioning, light conditioning, easy luggage transportation, cleanliness, information services, toilets, parking lots, and facilities for special needs users. Facilities that provide added value are additional services, including: prayer room, nursery, shopping facilities, restaurant, smoking room, children's playroom, ATM / money changer, internet / wifi, ticket purchase facilities, charging station, drinking water facilities, and executive lounge (Yuliana, 2017).

The satisfaction felt by customers will have a positive impact on the company, including encouraging the creation of customer satisfaction and the company's reputation will be more positive for society, especially for customers. This has become a business opportunity that can be used to open business services (Sholeha et all., 2018). This is also supported by research Siswanto \& Khasanah, (2019), Nadianingrum \& Saputra, (2020), Andari \& Mulyantomo, (2020), Widyaningrum, (2020) and research Vuspita, (2020). Which states that facilities have a positive and significant effect on customer satisfaction, which means that if the facilities are upgraded it will increase customer satisfaction.

PT. Wings Abadi Airlines or better known as Wings Air is one of the airlines in Indonesia that is part of the Lion Group company, which also houses Lion Air. This 
airline shares the flight code with Lion Air, so there is not much brand awareness being created. Wings Air was formed in 2003, and operated in the same year, to be precise on July 10, 2003, with the initial intention of fulfilling the requests of Lion Air passengers who wanted to travel to small islands in Indonesia, such as the islands of Nias, Lombok, Bima, and others. . Wings Air is indeed under the same company as Lion Air, however, the two airlines use different types of aircraft, if Lion dominantly uses Boeing 737-900ER aircraft, this airline mostly uses ATR 72-600 type aircraft. The ATR 72500 and ATR 72600 are aircraft manufactured by a French-Italian company. This type of aircraft is the mainstay of the airline under the Lion Group, because the airline has ordered 27 aircraft of this type, making it the largest operator of ATR-type aircraft in the world. At the beginning of its establishment, Wings Air received grants for the MD-80 and Bombardier Dash 8-300 aircraft from its parent company, namely the Lion Group (Lion Air). This grant aims to expand the reach of aviation destinations (Mellissa, 2019).

The private national airline Wings Air is now serving its new flight route by opening the Lombok-Bima route. The flight went through Lombok International Airport to Sultan Muhammad Salahuddin Airport which is also known as Bima Airport on Sumbawa Island, West Nusa Tenggara. Flights will be served using ATR 72 turboprop aircraft with a capacity of 72 economy class seats. Lombok and Bima are areas in West Nusa Tenggara Province. With the opening of this route, it will certainly make it easier for accommodation via air between cities or islands in West Nusa Tenggara. The opening of this route can further support tourism and economic growth that flies from Lombok to Bima and vice versa twice a day, as well as other Wings Air routes that operate in the West Nusa Tenggara region, as well as being a feeder for Lion Air (Rahayu, 2016).

The business world, especially in the service sector, is very developed at this time, one of the growing service businesses in Indonesia. One of the things that need to be considered in choosing a service as a facility. The more facilities available, the more comfortable it will be to customers (Maryati \& Husda, 2020). Two low-cost airlines (LCC), namely Lion Air and Citilink Indonesia, decided to remove free baggage facilities for domestic flight routes. This causes ticket prices to soar, because people have to pay for airplane tickets and luggage. Now the wing air airline has removed baggage facilities which resulted in a large number of passengers complaining and preferring to have flight services providing baggage facilities. This can have a bad impact on the wing air company to attract the hearts of consumers, because consumer satisfaction is lost due to the policy of eliminating baggage facilities because most airplane passengers who travel will definitely carry a lot of goods as souvenirs even if the needs of passengers For this reason, as a researcher I am interested in taking the title of the effect of removing baggage facilities on customer satisfaction at Wings Air

\section{Literature review}

Facilities $(X)$

Abolition of facilities and infrastructure is an activity to free facilities and infrastructure from the prevailing accountability for justifiable reasons. More operationally, the elimination of facilities and infrastructure is a process of activities 
aimed at removing / removing facilities and infrastructure from the inventory list, because these facilities and infrastructure are deemed not functioning as expected, especially for the benefit.

Facilities are physical resources that must exist before a service is offered to consumers. Facilities are something that is very important in the service business, therefore the existing facilities, namely the condition of the facilities, the completeness of interior and exterior designs and the cleanliness of the facilities must be considered, especially those that are closely related to what consumers feel directly. (Tjiptono, 2014)

According to Tjiptono, (2014) the facility indicators are as follows:

a. Special consideration / planning

Aspects such as proportion and consumption combined with services to provoke intellectual and emotional responses from users or service users.

b. Spatial planning

This element includes interior planning and architecture, such as the placement of luggage or cabin crew equipment in an airplane.

c. Fittings / furniture

Fittings / furniture function as a means of providing comfort, as a display or supporting infrastructure for aviation service users.

d. Messages conveyed graphically

Important and interrelated aspects in this element are visual appearance, placement of cabin crew, selection of physical forms such as flight manuals and safety equipment.

e. Supporting Elements

The existence of the main facility is incomplete without supporting facilities such as a place to eat and tools to cover the noise inside the plane.

\section{Customer Satisfaction (Y)}

Satisfaction is the feeling felt by someone that arises because of comparing the perceived performance against the desired expectations / expectations. If the performance does not meet expectations, the customer will not be satisfied. But if the performance is in accordance with expectations, the customer will feel satisfied as well as the customer will be very satisfied or happy if the performance exceeds expectations, (Kotler and Keller, 2016)

According to the theory Kotler \& Armstrong, (2014), the key to retaining customers is customer satisfaction which can be seen from:

a. Re-purchase: Buy back, where the customer will return to the company to look for goods / services.

b. Creating a Word-of-Mouth: In this case, the customer will say good things about the company to others.

c. Creating Brand Image: Customers will pay less attention to brands and advertisements than competitors' products. 
d. Creating Purchasing Decisions at the same Company: Purchasing other products from the same company.

Physical facilities are an indicator of whether the quality of a service is good or not. Facilities are closely related to forming customer perceptions. Thus, companies that want to maintain their existence and win business competition and attract customers' attention will always provide quality services and supporting facilities that are in accordance with the price paid by customers or trying to meet their needs and realize their expectations. The creation of customer satisfaction can provide several benefits, including a harmonious relationship between the company and customers, providing a good basis for repurchasing and creating customer loyalty, and forming a word of mouth recommendation that is beneficial for the company (Tiptono, 2016)

The formulation of the research hypothesis is as follows:

H1: Removal of Baggage Facilities Affects Customer Satisfaction on Wings Air Ho: Removal of Baggage Facilities no Affects Customer Satisfaction on Wings Air

\section{Research Methods}

This research uses a quantitative approach with a survey method. While this type of research is categorized as causal research. According to Husein, (2013) causal design is used to measure the strength of the relationship and influence between independent variables (facilities) on the dependent variable (customer satisfaction). The population in this study are consumers who have ever used air flight services using a wing airline. The sampling technique used in this study was purposive sampling, which is a sampling technique from a population based on certain criteria (Jogiyanto, 2010). The number of samples taken in this study were 50 respondents. The research instrument used a questionnaire with a Likert scale. Testing data using the validity test with a valid standard. A variable is said to be valid if it has a value of $r$ count $>0,300$, Reliability Test is consistent or stable from time to time to measure reliability with the Cronbach Alpha Statistical Test. A variable is said to be reliable if it has a Cronbach Alpha value $>0.600$ (Ghozali, 2016). Data analysis uses simple linear regression, the partial test with t test aims to determine the influence of each independent variable individually (partially) on the variable dependent. $\mathrm{T}$ test is done by comparing $\mathrm{t}$ count with $\mathrm{t}$ table. If $\mathrm{t}$ is greater than $t$ table at the confidence level of $95 \%$ or ( $p$-value $<0.05$ ), then Ha is accepted, which means that the independent variable that is partially tested has an influence on the dependent variable. Data analysis used simple linear regression with the following equation:

$\mathrm{Y}=\mathrm{a}+\beta 1 \mathrm{X} 1++\mathrm{e}$

Where :

Y : Customer Satisfaction

a : Constants

$\beta 1$ : Regression coefficient 
X1: Facilities

E : Error

\section{Discussion Result}

Data collection using questionnaires was carried out directly at Sultan HasanudinBimaAirport, researchers immediately gave questionnaires directly to Airline wing passengers who had just arrived at the passenger arrival area. The general description of respondents in this study can be seen from the characteristics of the respondents which include gender, age, and occupation inTable 1 below.

Table 1. Characteristics of Respondents

\begin{tabular}{llcc}
\hline Characteristics & \multicolumn{1}{c}{ Criteria } & $\begin{array}{c}\text { Number Of } \\
\text { Respondents }\end{array}$ & Percentage \\
\hline \multirow{2}{*}{ Gender } & a. Girls & 27 & 54 \\
\multirow{4}{*}{ Age } & b. Man & 23 & 46 \\
& a. $17-25$ & 24 & 48 \\
\multirow{4}{*}{ Profession } & b. $26-34$ & 14 & 28 \\
& c. 35 & 10 & 24 \\
& a. ASN (Civil Servant) & 9 & 18 \\
& b. Civil Servant & 5 & 10 \\
& c. Enterpreuneur & 5 & 10 \\
& d. College Student & 24 & 62 \\
\hline
\end{tabular}

Informatioan $\mathrm{n}=50$

Source: Primary data processed by SPSS v. 23, 2021

From the data above, it can be seen that the number of respondents is 50 people, which shows that from the criteria for sex the largest gain is from women by $54 \% .62 \%$ of the students' job criteria are because part of the wing airline passengers are students who return from their place of education because of the campus policy which implements online courses.

Testing the hypothesis in this study using simple linear regression analysis with the help of the SPSS 23.00 for Windows program to determine the effect of the Facility variable $(\mathrm{X})$ on customer satisfaction $(\mathrm{Y})$ partially. The results of the simple linear regression test in this study can be seen in the following table:

Table 2. Simple Linear Regression Test

\begin{tabular}{llllll}
\hline Model & \multicolumn{2}{c}{ Coefficients $^{\mathrm{a}}$} \\
& $\begin{array}{c}\text { Unstandardized } \\
\text { Coefficients } \\
\text { B }\end{array}$ & $\begin{array}{c}\text { Std. Error } \\
\text { Coefficients } \\
\text { Beta }\end{array}$ & Stardized & Sig. \\
\hline 1 (Constant) & 1.613 & 1.096 & & 1.417 & .148
\end{tabular}


Amenities

.429

.054

.756

$8.004 \quad .000$

a. Dependent Variable: Customer Satisfaction

Source: Primary data processed by SPSS v. 23, 2021

From the results of the regression analysis, it can be seen that the simple linear regression equation is as follows: $\mathrm{Y}=1.613+0.429 \mathrm{X}$

Based on this equation, it can be explained as follows:

a. A constant value of 1,613 means that if the Facility variable $(X)$ is considered zero, then Customer Satisfaction (Y) will be 1,613.

b. The value of the beta coefficient on the Facility variable $(X)$ is 0.429 , which means that every change in the Facility variable $(X)$ is one unit, it will result in a change in Customer Satisfaction $(Y)$ of 0.429 units, with other assumptions that are fixed.

Table. 3 Determination Test Results

Model Summary

\begin{tabular}{llccc}
\hline Model & R & R Square & $\begin{array}{c}\text { Adjusted R } \\
\text { Square }\end{array}$ & $\begin{array}{c}\text { Std. Error of } \\
\text { the Estimate }\end{array}$
\end{tabular}

\begin{tabular}{lllll}
\hline 1 & $.756^{\mathrm{a}}$ & .572 & .563 & 1.68286 \\
\hline
\end{tabular}

a. Predictors: (Constant), Amenities

Source: Primary data processed by SPSS v. 23, 2021

The coefficient of determination is a tool to measure the influence of independent variables on the dependent variable. The coefficient of determination ranges from 0 to 1 , the coefficient of determination is close to 1 , the greater the influence of the independent variable on the dependent variable. The results of the $\mathrm{R}$ Square test in this study obtained a value of 0.572 . This shows that Consumer Satisfaction is influenced by the Facility variable of $57.2 \%$ while the remaining $42.8 \%$ is influenced by other factors not included in this study.

Furthermore, to find out whether the elimination of baggage facilities has a significant effect on customer satisfaction, the test is done using the $t$ test. The test results can be explained as follows:

Table 4. Significant test results ( $\mathrm{t}$ test)

Coefficientsa

\begin{tabular}{llrrrrr}
\hline Model & \multicolumn{2}{c}{$\begin{array}{c}\text { Unstandardized } \\
\text { Coefficients }\end{array}$} & $\begin{array}{c}\text { Standardized } \\
\text { Coefficients } \\
\text { Beta }\end{array}$ & $\mathrm{t}$ & Sig. \\
& \multicolumn{1}{c}{ B } & Std. Error & Beta & & \\
\hline \multirow{2}{*}{1} & (Constant) & 1.613 & 1.096 & & 1.417 & .148 \\
& Amenities & .429 & .054 & .756 & 8.004 & .000 \\
\cline { 2 - 7 }
\end{tabular}

a. Dependent Variable: Customer Satisfaction

Source: Primary data processed by SPSS v. 23, 2021 
The statistical results of the $t$ test for the Facility variable obtained a $t$-count value of 8.004 with a t-table value of $1.67655(8.004>1.67655)$ with a significance value of 0.00 less than $0.05(0.000<0.05)$, so it can be stated that "Removal of Baggage Facilities has a positive and significant effect on Customer Satisfaction on the Wings Air airline." Proven "This is in accordance with the results conducted by Ardiawan, (2017), which states that there is a significant effect of facilities on consumer satisfaction at the Mareno 2 NgunutTulungagung Futsal Field and is strengthened by research Maryati \& Husna, (2020) which states that facilities have a significant effect. Towards Customer Satisfaction At Holiday Hotels in Batam City.

\section{Conclusion}

Based on the results of the research and discussion, the conclusion of the research results can be stated that the elimination of baggage facilities has a positive and significant effect on customer satisfaction on the Air Wings Airline. Thus it can be said that the facility has an important role in determining the level of customer satisfaction. Facilities are physical resources that must exist before a service can be offered to consumers. Facilities can also be anything that makes it easier for consumers to get satisfaction. If the customer is satisfied, he will show that he is likely to buy the same product again and will tend to provide good references for the product to others. Steps that can be taken to attract customer satisfaction can be done by prioritizing facilities. One of the company's strategies is that consumers are satisfied with the provision of facilities that can pamper consumers so that consumers' desire to switch to other products will be difficult to do because consumers are satisfied.

For the next researcher, the addition of research variables is to make the research better so that the results can be varied. The addition of new variables such as promotion, service quality and price can make further research more interesting and can explain the phenomenon of consumer satisfaction more comprehensively. The next researcher suggested doing similar research, such as examining other variables that had not been studied in this study.

\section{References}

Andari, Putri Maulida \& Mulyantomo, Edy, (2020). Pengaruh Kualitas Pelayanan, Fasilitas, Kepercayaan dan Promosi Terhadap Kepuasan Pelanggan (Studi Pada Pelanggan Hotel Pandanaran Semarang). Majalah Ilmiah Solusi,18(3). P-ISSN : 1412-5331 E-ISSN : 2716-2532

Ardiawan, Peni, (2017).Pengaruh Kualitas Pelayanan, Fasilitas, dan Lokasi terhadap Kepuasan Konsumen pada Lapangan Futsal Mareno 2 Ngunut Tulungagung. Simki-Economic, 2(1), ISSN : 2599-0748

Ghozali, Imam. (2016). Aplikasi Analisis Multivariete Dengan Program IBM SPSS 23 (Edisi 8). Cetakan ke VIII. Semarang : Badan Penerbit Universitas Diponegoro. 
Husein, Umar. (2013). Metode Penelitian untuk Skripsi dan Tesis. Jakarta: Rajawali

Jogiyanto, Hartono.(2010). Metodologi Penelitian Bisnis: Salah Kaprah dan PengalamanPengalaman. Edisi Pertama. BPFE. Yogyakarta.

Kotler, P. and Keller, K.L. (2016). Marketing Management, 15th Edition New Jersey: Pearson Pretice Hall, Inc.

Kotler, P. dan Amstrong G. (2014). Principle of Marketing, 15th edition. New Jersey: Pearson Pretice Hall.

Lumentut, F. L., \& Palandeng, I. D. (2014). Fasilitas, Service scape, Dan Kualitas Pelayanan, Pengaruhnya Terhadap Kepuasan Konsumen Mcdonald's Manado. Jurnal EMBA, 2(3), 126-136

Markus, (2020). Pengaruh Kualitas Pelayanan dan Fasilitas Terhadap Kepuasaan Pelanggan (Studi Kasus Pada Spbu Muara Siban Kecamatan Pulau Pinang Kabupaten Lahat . MOTIVASI JurnalManajemen dan Bisnis, 5(2)

Maryati, Feni \& Husda, Elfi Nur. (2020). Pengaruh Fasilitas dan Kualitas Pelayanan Terhadap Kepuasan Pelanggan Pada Holiday Hotel di Kota Batam. Jurnal Magisma,8(1)

Mellissa, Vanessa. (2019) .Fasilitas serta fakta menarik dari wing air.https://www.futuready.com/artikel/travel/wings-air/. Diakses 10 Januari 2021

Nadianingrum, Wahyu Nurul \& Saputra, Asron, (2020). Pengaruh Kualitas Pelayanan dan Fasilitas Terhadap Kepuasan Konsumen Pada PT. Capella Dinamik Nusantara. ejournalymbz, 3(3)

Rahayu, TrisnaJuwita. (2016). Wings Air Layani Penerbangan Lombok-Bima. https://travel.kompas.com/read/2016/02/25/170900527/Wings.Air.Layani.Pe nerbangan.Lombok-Bima. Diakases 10 Januari 2021

Sadiqin, Hanis M \& Saraswati, Trisha Gilang Trisha, (2018). Pengaruh Kualitas Pelayanan Terhadap Kepuasan Pelanggan Pada Maskapai Lion Air (Studi Pada Mahasiswa Administrasi Bisnis Universitas Telkom). e-Proceeding of Management, 5(3), ISSN : 2355-9357

Sholeha, Ludviyatus, Djaja Sutrisno \& Widodo, Joko, (2018). Pengaruh Kualitas Pelayanan Terhadap Kepuasan Pelanggan Di Ahass Sumber Jaya Maha Sakti Kecamatan Rogojampi Kabupaten Banyuwangi. Jurnal Pendidikan Ekonomi, 12(1)

Siswanto, Dimas \& Imroatul, Khasanah, (2019). Analisis Pengaruh Kualitas Pelayanan, Fasilitas dan Nilai Pelanggan Terhadap Kepuasan Pasien (Studi Pada Pasien Ruang Rawat Inap Rumah Sakit Pku Muhamadiyah Gombong). Diponegoro Journal Of Management , 8(1), 38-46 
Soemitro, A. R. A., dan Suprayitno, H. (2018). Pemikiran Awal tentang Konsep Dasar Manajemen Aset Fasilitas. Jurnal Manejemen Aset Infrastruktur \& Fasilitas, 2(1), 1-14. https://doi.org/10.12962/j26151847.v2i0.4225

Srijani, Ninik \& Hidayat, Sukma Achmad, (2017). Pengaruh Fasilitas Terhadap Kepuasan Pelanggan Di Aston Madiun Hotel \& Conference Center. Jurnal Penelitian Ilmu Ekonomi Wiga Vol. 7(1), 31 - 38

Sulastiyono, Agus. (2011). Manajemen Penyelenggaraan Hotel. Seri Manajemen Usaha Jasa Sarana Pariwisata dan Akomodasi. Bandung: Alfabeta.

Tjiptono, Fandy.(2014). Pemasaran Jasa (Prinsip, Penerapan, Penelitian). Yogyakarta. Andi.

Tjiptono, Fandy.(2016). Service, Quality \& satisfaction. Yogyakarta. Andi.

Vuspita, Heryenzus, (2020). Pengaruh Kualitas Pelayanan dan Fasilitas Terhadap Kepuasan Konsumen Kaliban Hotel. Jurnal Ilmiah Kohesi, 4(3)

Widyaningrum, Devi Ika , (2020). Pengaruh Kualitas Pelayanan dan Fasilitas Terhadap Kepuasan Dan Loyalitas Pelanggan Hotel Luminor Mangga Besar Jakarta Barat . Jurnal STEI Ekonomi, 20(20).

William \& Purba, Tiurniari, (2020). Kualitas Pelayanan dan Fasilitas Terhadap Kepuasan Pelanggan Pada Bengkel Mazda di Kota Batam. Jurnal EMBA, 8(1), 1987-1996

Yuliana, Dina. (2017).Pengaruh Fasilitas, Layanan dan Informasi Aksesibilitas Terhadap Tingkat Kepuasan Penumpang Di Bandara Husein Sastranegara Bandung Warta Ardhia Jutnala perhubungan Udara, 43(1), 27-42

Yunus \& Budiyanto. (2014). Pengaruh Kualitas Pelayanan dan Fasilitas Terhadap Kepuasan Pelanggan. Jurnal Ilmu \& Riset Manajemen, 3(12) 